\title{
Review \\ The Wingate Anaerobic Test, a Narrative Review of the Protocol Variables That Affect the Results Obtained
}

\author{
Arkaitz Castañeda-Babarro
}

Citation: Castañeda-Babarro, A. The Wingate Anaerobic Test, a Narrative Review of the Protocol Variables That Affect the Results Obtained. Appl. Sci. 2021, 11, 7417. https://doi.org/ 10.3390/app11167417

Academic Editor: Mark King

Received: 23 July 2021

Accepted: 9 August 2021

Published: 12 August 2021

Publisher's Note: MDPI stays neutral with regard to jurisdictional claims in published maps and institutional affiliations.

Copyright: (C) 2021 by the author. Licensee MDPI, Basel, Switzerland. This article is an open access article distributed under the terms and conditions of the Creative Commons Attribution (CC BY) license (https:// creativecommons.org/licenses/by/ $4.0 /)$.
Health, Physical Activity and Sports Science Laboratory, Department of Physical Activity and Sports, Faculty of Psychology and Education, University of Deusto, 48007 Bilbao, Spain; arkaitz.castaneda@deusto.es

\begin{abstract}
The Wingate Anaerobic Test (WAT) has been widely used since its creation in 1974 . The WAT involves performing a $30 \mathrm{~s}$ "all-out" cycling test. The test is currently applied with some modifications, partly due to the evolution of the material used to perform it. The purpose of this text is to act as a guide for the correct use and application of the test, as well as to highlight the importance of controlling many of the variables that may influence its results. Methods: A literature search was conducted in PUBMED/MEDLINE and Web of Science with different combinations of keywords all related to the WAT to obtain a search of 113 papers. Results and discussion: It was observed that variables such as the duration of the test or the resistance used in the cycle ergometer must be adjusted according to the objective and the population evaluated, while others such as the warm-up or the supplementation of different substances can improve performance on the WAT. Conclusions: In order to apply the WAT correctly, variables such as duration, resistance used or warm-up time and intensity must be adjusted according to the evaluated subjects and the aim of the study. Other variables such as position on the bike or equipment used should also be controlled if we want to guarantee its replicability.
\end{abstract}

Keywords: anaerobic; power; protocol; reliability; reproducibility; supplementation

\section{Introduction}

\subsection{The Wingate Anaerobic Test, Origin and Relevance}

Originally based on the Cumming test [1] the Wingate Anaerobic Test (WAT) was developed at the Department of Sports Medicine and Research of the Wingate Institute for Physical Education and Sport in Israel during the mid and late 1970s [2]. Since the introduction of its prototype in 1974 [3], the WAT has been used in various laboratories, both as a test that assesses anaerobic performance and as a standardised effort to analyse responses to supra-maximal exercises.

The purpose of the WAT is to evaluate the availability of ATP-Phosphocreatine reserves (quantity and speed) using the phosphogenic system (Phosphocreatine) and glycolytic metabolism by measuring the power generated in an all-out cyclo-ergometer test (exercise performed at maximum intensity without distribution of effort from start to finish) $[4,5]$. It was designed to be administered in a simple manner, without the need for specifically trained personnel, at low cost, and performed with accessible equipment such as the Monark ergometer or cyclo-ergometers equipped with similar mechanisms. It was also devised to be non-invasive, aimed at quantifying muscle performance through indirect variables (physiological or biomechanical) and feasible to administer to a broad spectrum of the population (including children and the physically handicapped). Furthermore, it is based on the assumption that anaerobic performance is a local rather than systemic characteristic and that the test could be applicable to both upper and lower limbs.

In retrospect, since its origins as a measure of anaerobic power and capacity in 1974, the WAT has gained wide acceptance as an important assessment test to determine anaerobic performance. Several studies were carried out on modifications to optimal load and/or 
load duration in a variety of populations (these will be studied in more detail below). This has led to its evolution over the years, with many variants and modifications in its application in different research study designs. It is probably the most widely used anaerobic test. It has also served as a basis for the design of newer tests of a similar nature [6] and other performance-based protocols, such as the Sprint Interval Test [7]. Furthermore, it was deemed objective, reliable, valid and sensitive to improvement or deterioration of anaerobic performance rather than to overall good health.

In order to determine the validity of a test, it must be compared to a gold standard protocol that is known to produce accurate and reliable results. However, there is no gold standard protocol for measuring anaerobic capacity or power [8]. Instead, the WAT was compared to laboratory results, sports performances and sports specialities in order to verify its validity as a test protocol. These aspects will be covered in greater detail in the following sections, although we can already state that the original WAT only seems to have validity for control of Peak Power (PP), not for Mean Power (MP) or Fatigue Index (FI) [9].

In terms of the reliability obtained in the different researches conducted, the results depend on the measured variable being referred to. In the case of PP and MP, they indicate that it is a precise and valid indicator [10]. Therefore, the WAT can be used as a valid and reliable predictor of anaerobic capacity and power [11]. WAT reliability coefficients (test-retest comparisons $p<0.05)$ are good for PP $(r>90)[9,11]$ and MP (between 0.91 and 0.93 ) $[3,12-14]$. On the other hand, FI reliability is low $r=0.43-0.73$ [1].

In a study carried out with eleven healthy, moderately-trained males, comparing six sprints on a bicycle ergometer on four different occasions, which were separated by a minimum of 1 day and a maximum of 7 days, maximum power was significantly higher $(4.9 \% ; r<0.05)$ in trial 2 compared to trial 1 , whilst there was no difference observed between trials 2, 3 and 4 [15]. A familiarisation session is therefore likely to be useful in improving the reliability of PP and MP, although FI reliability remains low even after familiarisation sessions [9], probably because it depends largely on aerobic metabolism [16].

\subsection{Protocol and Information Provided by the WAT}

First of all, it is important to know how this test was initially designed and its original protocol in order to then give the guidelines for its possible adaptations.

The WAT requires pedalling with lower or upper limbs for $30 \mathrm{~s}$, at maximum speed and against constant resistance. It is important to make the athlete understand that this is a maximum effort test. It is also important to know that maximum pedalling cadence peaks within $5 \mathrm{~s}$ of the test starting. Resistance is predetermined to produce supra-maximal mechanical power (equivalent to $2-4$ times maximum aerobic power) and to elicit a noticeable increase in fatigue (i.e., a drop in mechanical power) within the first few seconds.

In its simplest form, a cyclo-ergometer or mechanical bicycle can be used that has a device enabling the load to be added manually, as well as a revolutions per minute counter and a stopwatch to record these revolutions every five seconds. In laboratories, this equipment is often used for the above-mentioned types of tests.

The original version of the WAT recorded the following activities [10]:

- Warm-up: Roll 3-4 min at $60 \mathrm{rpm}$ with $60 \mathrm{w}$ (women) and $90 \mathrm{w}$ (men), with two or three 3-4 s sprints being interspersed at maximum speed;

- After the warm-up: The subject rests for 2 min before performing the test;

- The original test weight/load used for the WAT was 7.5\% of the participant's body mass, or $0.075 \mathrm{~kg}$ per $\mathrm{kg}$ of body weight [3]. This original workload was selected based on the use of young subjects rather than on adult (>18 years) or athletic populations The test is carried out as follows:

A. Body mass $(\mathrm{kg})$ is calculated by weighing with the minimum possible clothing/accessories;

B. The weight/resistance that will be applied to the subject in the test is calculated: $7.5 \%$ of the participant's body mass, i.e., the subject's body weight in kg.0.075. 
The test: the subject starts pedalling at $60 \mathrm{rpm}$ for about $10 \mathrm{~s}$ without resistance, and there is a 3 s countdown, after which the test resistance is set and the subject pedals at maximum power output for $30 \mathrm{~s}$. The last $3 \mathrm{~s}$ of the test will be counted down. Once finished, the subject continues to ride at 60-80 rpm without resistance for at least 2-3 min.

Although the test was originally designed with a jump-start, i.e., before starting the test, the subjects were asked to start pedalling as quickly as possible (without a load). Once they had reached about 80 revolutions per minute, the load was placed on the cycloergometer and the stopwatch was started. This procedure was used to reduce any error associated with the work required to accelerate the flywheel. However, nowadays, most authors carry out the test with a stopped start, in the same way as a track cyclist would in a $500 \mathrm{~m}$ race, as cyclo-ergometers are capable of recording data from each of the pedalling operations performed.

The information we can obtain from the test is as follows [17]:

1. Peak Power: The highest level of power reached during the test is usually within the first $10 \mathrm{~s}$ if the test is performed properly. With electromagnetic cyclo-ergometers equipped with force sensors on the pedals or mechanical cyclo-ergometers equipped with high-resolution pedalling speed sensors, it is possible to calculate maximum instantaneous power in one pedalling $[18,19]$, which is a good measure of maximum anaerobic power. This value indicates the power generation capacity of the ATPPCr system;

2. Relative PP: This value is obtained by dividing peak power by the weight of the subject. This result is of greater use than the previous one for the purpose of comparing subjects, since relatively speaking, a subject with less mass can reach higher energy levels than an athlete with more mass. PEmax $=$ Pmax $/$ mass $(\mathrm{kg})$. The result is given in $\mathrm{w} / \mathrm{kg}$;

3. Mean power: The average power reached over $30 \mathrm{~s}$. This value represents the capacity to produce energy through the ATP-PCr system and glycolytic metabolism-anaerobic capacity;

4. Mean relative power: This value is obtained by dividing average power by the weight of the subject.

5. Fatigue Index: The FI represents the loss of power experienced from the moment maximum power is reached and the end of the test [18] or, in other words, the fatigue rate is the rate of decrease in power during the test, expressed as a percentage of maximum power [2] and is related to the total capacity to produce energy through ATP-PCr and glycolytic metabolism. It is the least reliable and valid of the data provided by the WAT. However, it is very sensitive to training effects and sporting speciality, to the extent that elite track cyclists specialising in endurance disciplines have much lower fatigue rates than elite track cyclists specialising in sprint disciplines [18]. It is obtained as follows: (Equation (1) Formula for obtaining the Fatigue Index)

$$
\mathrm{FI}=(\mathrm{PP}-\text { Minimum power }) / \mathrm{PP}) \times 100
$$

Another value to take into account is the time needed to reach PP, as the shorter the time needed to reach this value, the shorter the time required to recruit muscle fibres. A longer time to reach PP will indicate subjects with fewer possibilities to recruit muscle fibres and motor units in a faster and more coordinated manner, demonstrating poor capacity for this type of work. This value is therefore related to the proportion of fast fibres to slow muscle fibres, allowing the percentage of fast fibres to be estimated. Thus, the results are important for talent identification or monitoring of training progress in track sprint cyclists. Another indicator of the type of fibres in the majority of test subjects is the analysis of the decrease in power levels. People with a higher percentage of fast contraction fibres will generate higher output power with a corresponding greater decrease over time [20].

Originally, it was assumed that peak power reflected the alkali anaerobic processes (phosphagen) and average power, the rate of anaerobic glycolysis in the muscle. A study 
by Jacobs et al. [21] showed that muscle lactic acid rises to extremely high levels in the first $10 \mathrm{~s}$ after starting the test, and therefore it is unlikely that PP reflects only alactic processes. It is safe to assume, however, that PP is a reflection (rather than a direct measurement) of the ability of the muscles of the respective limbs to produce a high mechanical power level in a short time.

Different considerations to be taken into account when carrying out the "original" test:

- The test should be carried out while the subject is seated on the bike during the entire test;

- It is of vital importance that the test be carried out to the maximum from the beginning; otherwise, the values recorded will not be reliable;

- Although cyclo-ergometers currently in use are taken into account, there are not too many problems in this respect, and it is important that the sampling frequency recorded to be as high as possible [22].

Taking into account the importance of this test, its great usefulness and the large number of studies that have chosen it, a review of the literature seems necessary to analyse the correct protocol to be applied and the variables that can condition performance on the test. A large amount of literature published on this test suggests that there will be several variables to consider and many factors that must be controlled before carrying out the test in order to obtain reliable and replicable results. The aim of this review is to analyse the variables of the protocol that affect the result in the application of the WAT.

\section{Methods}

A literature search was conducted in PUBMED/MEDLINE and Web of Science. Relevant studies published in English until 2021 were gathered. The main search terms in the title and abstract included the following: "wingate, protocol", "wingate, origin", "wingate, duration", "wingate, resistance", "wingate, warm-up", "wingate, supplementation", "wingate, sodium bicarbonate", "wingate, creatine", "wingate, $\beta$-Alanine", "wingate, caffeine", "wingate, nitrate", "wingate, genetic" and "wingate, polymorfism".

We excluded all studies with no apparent outcomes of interest and the following study types: case reports, letters, commentaries and editorials. From an initial search of 1713 papers, abstracts were reviewed to select a total of 107 papers. After reviewing the references of the most important papers, another five were included, for a total search of 113 papers.

\section{Results and Discussion}

\subsection{Influential Variables in the Wingate Anaerobic Test}

The following table shows the most important variables investigated and their effect on the performance of the WAT (Table 1).

Table 1. Summary of the most important variables reviewed and their effect on the WAT. PP: Peak Power; MP: Mean Power; FI: Fatigue Index.

\begin{tabular}{cc}
\hline Variable & Effect \\
\hline Duration & $\begin{array}{c}\text { Adjust the duration between } 6-10 \mathrm{~s} \text { and } 45-60 \mathrm{~s} \text { depending on the variable to } \\
\text { be evaluated (PP, MP, FI) and the fitness level of the subjects }\end{array}$ \\
\hline Cyclo-ergometer resistance & $\begin{array}{c}\text { An amount of } 0.075 \mathrm{~kg} / \mathrm{kg} \text { is insufficient and should be adjusted according to } \\
\text { variables such as gender, physical condition and weight }\end{array}$ \\
\hline Warming up & $\begin{array}{c}\text { For untrained subjects, a submaximal warm-up (5-10 min) could be enough; in } \\
\text { trained subjects, performing some high-intensity exercise after the submaximal } \\
\text { warm-up could be recommended }\end{array}$ \\
\hline Sodium bicarbonate (NaHCO32) & Supplementation \\
\hline
\end{tabular}


Table 1. Cont.

\begin{tabular}{|c|c|}
\hline Variable & Effect \\
\hline Creatine & $\begin{array}{l}\text { With sufficient duration of intake and sufficient dosage, it seems to produce } \\
\text { positive effects. }\end{array}$ \\
\hline$\beta$-Alanine & It seems not to produce any improvement \\
\hline Caffeine & $\begin{array}{l}\text { With sufficient duration of intake and sufficient dosage, it seems that it } \\
\text { produces improvements. }\end{array}$ \\
\hline \multirow[t]{2}{*}{ Nitrate } & It seems that it doesn't produce improvements in performance \\
\hline & Genetic variables \\
\hline ACTN3 & Contradictory results \\
\hline AMPD1 & Positive effects \\
\hline PPARA & Positive effects \\
\hline MCT1 T1470A & Positive effects \\
\hline UCP2 & Positive effects \\
\hline
\end{tabular}

\subsubsection{Duration}

One of the biggest disadvantages of the WAT is the sequelae that can be caused by the high acidosis reached due to the large glycolytic component of the same [23]. As a result, one of the main objectives of researchers when studying the suitable or sufficient duration of the test was to reduce or avoid these sequels. With this objective in mind, some research was carried out to ascertain the suitability and reliability of a shorter test.

On the one hand, Attia et al. [24] studied 81 exercise science students, who also played team sports, to see whether the power levels obtained in a $20 \mathrm{~s}$ test could predict those obtained in an original $30 \mathrm{~s}$ test, concluding that the power data obtained in the $20 \mathrm{~s}$ test predicted those obtained in the original time test. In the same vein, Stickley et al. [25] researched whether a $20 \mathrm{~s}$ test could predict the results of the $30 \mathrm{~s}$ test on female university students, also ascertaining its reliability. Finally, with a cross-validation design, [26] a study was conducted with 77 subjects, in which it was concluded that the WAT of $20 \mathrm{~s}$ could become a valid and sensitive protocol to replace the traditional $30 \mathrm{~s}$ WAT.

Herbert et al. [27] focused on maximum power instead and compared PP levels in a $6 \mathrm{~s}$ test and the original $30 \mathrm{~s}$ test on nine active men, finding very similar PP levels in the two tests, albeit being able to avoid the side effects of a longer test such as the $30 \mathrm{~s}$ test. Hachana et al. [28] made the same comparison as the previous researchers but compared a $15 \mathrm{~s}$ test with the $30 \mathrm{~s}$ test with 43 young physical education students. In addition to the positive relationship that they were expected to find in the maximum power of the two test durations, they also found a positive relationship in the average power levels obtained in the two different tests, although not in the fatigue index, which proved to have no relationship in the comparison made between the 15 and $30 \mathrm{~s}$ tests. Furthermore, intending to achieve a positive relationship in the FI, Laurent et al. [29] managed to validate a $20 \mathrm{~s}$ test performed by 50 male students using a derived regression equation, which enabled them to predict the results of the $30 \mathrm{~s}$ test with a $20 \mathrm{~s}$ one. Unlike previous studies, Zajac et al. [23] researched the relationship of the power levels generated in two $10 \mathrm{~s}$ and $30 \mathrm{~s}$ tests on 24 top-level athletes, finding that the PP obtained in the $10 \mathrm{~s}$ test was higher than that reached earlier. In addition, as can be expected from the presence of higher lactate concentrations recorded after the $30 \mathrm{~s}$ test, the latter would be more suitable than the $10 \mathrm{~s}$ test for assessing anaerobic capacity.

In order to use the $30 \mathrm{~s}$ test duration to evaluate competitive cyclists who had to compete in events longer than $30 \mathrm{~s}$, but which still required a significant anaerobic component, Carey et al. [30] evaluated the differences in PP, MP and FI obtained in three tests lasting 30,60 and $75 \mathrm{~s}$, only obtaining similarities in the PP level. Lastly, studies that focused on the suitable duration of the test for the evaluation of anaerobic capacity would seem to 
recommend a test of a slightly longer duration. For example, Craig et al. [31] conducted research on nine trained cyclists to ascertain which duration between 10, 30, 40 and $60 \mathrm{~s}$ would be the most appropriate to evaluate both power and anaerobic capacity, based on the work generated, lactate concentrations and power levels obtained. Their conclusion was that the most appropriate duration would be $60 \mathrm{~s}$. Later, Withers et al. [32] studied the most appropriate duration of the test-30-60 or $90 \mathrm{~s}$ - to assess anaerobic capacity in 6 males, based on lactate concentrations and oxygen deficit. They concluded that 60 and $90 \mathrm{~s}$ were the most appropriate durations in this case. Along the same lines, Calbet et al. [18] researched the most appropriate duration between 30 and $45 \mathrm{~s}$ based on the oxygen deficit during the test in order to evaluate the anaerobic capacity in 19 trained males, concluding that 45 s duration was the most appropriate for such cyclists. However, in most subjects, it is still insufficient to allow full utilisation of anaerobic capacity (many of them only used $80-90 \%$ of their anaerobic capacity). On the other hand, in elite track cyclists, they observed that full anaerobic capacity could be used in a test lasting between 40 and $50 \mathrm{~s}$ [19]. Vandewalle et al. [33] also claim that the duration of the test is insufficient for the purpose of suitably measuring the subjects' anaerobic capacity.

It is important to remember that different values are obtained from the WAT-peak power, fatigue index and average power, among others. Thus, the duration of the test deemed suitable for the measurement of one value may be different from the duration recommended for another value. It is also important to take into account that, depending on the subject's level of physical condition, speciality or genetics, etc., the duration may also need to be varied.

Therefore, it seems that depending on what our purpose is when performing the WAT, we can adjust its duration. Although it appears that in a young athletic or active population, a $20 \mathrm{~s}$ test could predict the result of the $30 \mathrm{~s}$ test, a 6 to $10 \mathrm{~s}$ test would be sufficient to obtain $\mathrm{PP}$ in any case. When assessing the anaerobic capacity of trained subjects, the duration of the test should be increased to $45-60 \mathrm{~s}$.

\subsubsection{Resistance of the Cyclo-Ergometer}

Choosing a force load for each subject that produces the highest possible power peak and high average power is an important and, so far, only partially solved challenge. The strength originally suggested by the Wingate group was based on a study of a small group of young untrained individuals and has since been found to be too low or insufficient for most adults. The question of the optimal strength of the WAT has mainly been studied empirically by repeating this test with different loads in various populations. A priori, it seemed evident that the same load was optimal for maximum power, average power and fatigue rate in the WAT.

The first study into suitable resistance for the test was the one carried out by Evans et al. [14] on 12 highly trained adults, in which they concluded that resistance in the WAT has to be established in connection with anthropometric measurements, weight and volume of the subjects' legs. A couple of years later, Dotan et al. [34] agreed with previous researchers, stating that the strength of the test must be related to body somatotype and body composition. However, they added that it must be, above all, a function of the subject's level of physical fitness and recommend a strength of $0.087 \mathrm{~kg} / \mathrm{kg}$ for active male students. They also confirmed that the optimum strength for PP was higher than necessary so as to maximise MP. A few years later still, Bar-Or [10] recommended using a braking force of $0.095 \mathrm{kp} / \mathrm{kg}$ in non-sporting adults and 1 in adult athletes ( $>18$ years). In the case of the obese, women or children, these figures should be lower (Table 2). 
Table 2. Cyclo-ergometer resistances suitable for WAT. Table obtained from [10].

\begin{tabular}{cc}
\hline \multicolumn{1}{c}{ T (Torque) $=$ G (Body Weight $) \times \mathbf{C}($ Standard $)$} \\
\hline Leg Ergometry & X Body Weight $=$ Torque $($ in $\mathbf{N m})$ \\
\hline Male adult & 0.7 \\
Athlete male adult & 0.8 \\
Female adult & 0.67 \\
Athlete female adult & 0.77 \\
Boys (age 7-14) & 0.55 \\
Girls (age 7-14) & 0.53 \\
\hline
\end{tabular}

In 1985, Patton et al. [12] studied two different resistances in 19 young males, concluding that the resistance initially recommended for the test $(0.075 \mathrm{~kg} / \mathrm{kg})$ did not seem to be the most suitable for the purpose of obtaining the highest PP and PM levels. Later, Bradley et al. [35] studied which was the most suitable resistance between 0.075-0.085-0.095 and $0.105 \mathrm{~kg} / \mathrm{kg}$ of body weight in 46 women from different types of sport and 25 nonathletes, observing that the greater the resistance applied, the greater the PP obtained in the test. They also stated that the most suitable resistance for this population would be $0.105 \mathrm{~kg} / \mathrm{kg}$ of body weight, even higher, while to obtain the highest MP, suitable resistance was $0.085 \mathrm{~kg} / \mathrm{kg}$ of body weight.

Both Linossier et al. [36] and Bediz et al. [37] studied suitable resistance in 15 untrained subjects and 30 sedentary university students, respectively, and both concluded that the highest PP levels recorded were with a higher resistance than the original, namely $0.084 \mathrm{~kg} / \mathrm{kg}$ body weight and 0.095, respectively. According to Jaafar et al. [38], who carried out research on 16 university PE students, the highest PP was $11 \%$ of body weight. This same author, together with other colleagues, Jaafar et al. [39], compared the most suitable resistance for assessment of PP, MP and FI in 10 recreational and 10 highly trained subjects, concluding that both groups have a higher resistance than the original one $(10 \%$ and $11 \%$ of the body mass, respectively). They considered the fact that trained subjects need a higher level of resistance than untrained ones. Lastly, two studies were conducted on elite cyclists, namely that by Richmond et al. [40] with 29 (13 girls), and by Hermina [41] on 15 cyclists (male). The former compared resistances of 0.08 and $0.095 \mathrm{~kg} / \mathrm{kg}$ body weight and recommended a resistance of $0.095 \mathrm{~kg} / \mathrm{kg}$, while the latter compared resistances of between 7.5-10.5-12.5 and $14.5 \%$ body weight in order to achieve greater power in a $15 \mathrm{~s}$ test.

By administering a force equivalent to $0.5 \mathrm{~J} / \mathrm{rev} / \mathrm{kg}$ higher or lower than the optimum, it underestimates the average power by only 3 to $-5 \%$ in the men and women who performed the test [34]. In conclusion, the force needed to produce peak power is 20 to $30 \%$ higher than originally suggested. This seems to depend on the subject's level, being higher among athletes (particularly those engaged in events requiring greater power). This value is also higher in adults than in children and secondarily higher in men than in women. The force required to produce the highest PP is greater than that required for the highest MP.

Other authors make certain contributions regarding the resistance applied in the test; Üçok et al. [42], for example, claimed that it is more appropriate to use a resistance based on lean mass rather than the total mass of the subject, and obtained the highest PPs of between 90, 100 and $110 \mathrm{gr} / \mathrm{kg}$ of lean mass, with 100 and $110 \mathrm{gr} / \mathrm{kg}$.

On the other hand, the test was originally designed with a jump start, i.e., before starting the test, the subjects were asked to start pedalling as quickly as possible (without a load) and, once they had reached about 80 revolutions per minute, the load was then placed on the cyclo-ergometer, and the stopwatch was started. This procedure was used to reduce any error associated with the work required to accelerate the flywheel. However, today, most authors carry out the test with stopped output, as cyclo-ergometers and data collection systems are very different. Related to this, MacIntosh et al. [43] placed more importance on starting the stop test, instead of soft pedalling, rather than the resistance that was used in the test, in order to obtain the highest PP. Vargas et al. [44] reached the same conclusion as the previously-mentioned authors, affirming that with stationary starting, 
the traditional resistance can be enough to obtain the highest values of power in subjects involved in recreational activity.

Therefore, it appears that a higher resistance is needed to obtain the highest PP. However, in order to obtain the highest MP, this resistance should be higher in women than in children and in men than in women. Furthermore, it seems that the initial recommendation of $0.075 \mathrm{~kg} / \mathrm{kg}$ is insufficient and should be adjusted according to variables such as gender, physical condition and weight (the subject's lean mass and especially the subject's lower body lean mass).

\subsubsection{Warming Up}

Although several modifications and recommendations were made in this respect, the United States Olympic Committee, in 2004, made the following recommendations regarding the WAT warm-up:

- For road cyclists:

1. Women: 5 min with a $2 \%$ resistance of total body weight, perform three sprints of $5 \mathrm{~s}$ each at minutes $2-3$ and 4 with a $3.7 \%$ resistance of total weight. After the warm-up and before starting the test: a 3 min break;

2. Men: 5 min with a $2 \%$ resistance of total body weight, perform three sprints of $5 \mathrm{~s}$ each at minutes $2-3$ and 4 with a $4.1 \%$ resistance of total weight. After the warm-up and before starting the test: a 3 min break.

- For track athletes/sprinters:

1. Women: 5 min with a $2 \%$ resistance of total body weight, perform three sprints of $5 \mathrm{~s}$ each at minutes $2-3$ and 4 with a $5 \%$ resistance of total weight. After the warm-up and before starting the test: a 3 min break;

2. Men: 5 min with a $2 \%$ resistance of total body weight, perform three sprints of $5 \mathrm{~s}$ each at minutes $2-3$ and 4 with a $6.6 \%$ resistance of total weight. After the warm-up and before starting the test: a 3 min break.

Although taking into account the population on which the test was conducted, we should probably be cautious about the conclusions. Inbar and Bar-Or [3] conducted a study on children between 7 and 9 years old, whereby without knowledge of the concept of warm-up, they performed the test with and without a previous intermittent $15 \mathrm{~min}$ (30 s of activity and $30 \mathrm{~s}$ without activity) warm-up on a treadmill. Warm-up improved average power by $7 \%$ but did not affect PP. This improvement was consistent and highly significant from a statistical point of view. Furthermore, unpublished data from this study on these subjects have suggested that intermittent heat input (from this study onwards) was more effective than continuous 15 min heat input. Poprzęcki et al. [45] found no difference in the power levels generated in physical education students performing a 15 min warm-up at $60 \mathrm{rpm}$ at $50 \% \mathrm{VO}_{2}$ max or otherwise.

In other research with a similar population sample (physical education students), the 15 min duration warm-up improves the MP and PP when associated with a recovery interval prior to exercise of $5 \mathrm{~min}$. However, the $5 \mathrm{~min}$ warm-up duration allows better improvement of power output when the exercise is applied immediately after the warmup. Consequently, the duration of warm-up and the following recovery interval when practising or assessing activities requiring powerful lower limb muscle contractions must be taken into account [46].

In the case of track cyclists, Tomaras et al. [47] compared the performance obtained in a WAT after a traditional warm-up (20 min at progressive intensity and four sprints with breaks between them) with a shorter warm-up of $15 \mathrm{~min}$ of progressive intensity and a single sprint, concluding that the traditional track cyclist's warm-up results in significant fatigue, which corresponds with impaired PP output. A shorter and lower-intensity warmup permits a better performance. With a sample of similar characteristics, Doma et al. [48] compared a submaximal warm-up with a warm-up that included $10 \mathrm{~s}$ periods of overload, finding significant improvements with the warm-up performed at higher intensities. 
Lastly, it is important to take into account whether or not to perform stretchingstatic in this case-in the heating protocol since passive stretching after heating on a cyclo-ergometer significantly reduces the power generated later in the WAT [49].

Warm-up protocols may have significantly different impacts on PP during the WAT. Although more research is needed, developing a standardised warm-up protocol for the WAT may improve consistency between studies [50].

It seems that for untrained subjects in this type of test, a submaximal warm-up (5-10 min) could be enough to obtain their best performance, while in trained subjects, it would be recommended to perform some high-intensity exercise after the submaximal warm-up. More data are certainly needed to build an optimal heat input protocol for the WAT, and this may depend on factors such as subjects' age and general health and on climate features.

\subsubsection{Supplementation}

Sodium Bicarbonate (NaHCO32)

Regarding bicarbonate supplementation, Zabala et al. [51] found no improvement in the power level reached on the WAT in elite BMX riders. For their part, however, Douroudos II et al. [52] did find improvements in performance following sodium bicarbonate supplementation after having administered the same supplemented amount as in Zabala's group ( $0.3 \mathrm{~g}$ for each $\mathrm{Kg}$ of weight) to one of the second research groups. Other scientists [53] also obtained a small but insignificant improvement in active individuals by supplementing them with the same amount of sodium bicarbonate as in previous research

Although the results may seem contradictory, a meta-analysis by Lopes-Silva [54] concludes that chronic but not acute NaHCO3 intake increases both the WAT peak and average power. The latest publication by Jieting Wang, J et al. [55] confirms the above statement, as they supplied $0.2 \mathrm{gr} / \mathrm{kg}$ between 60 and $90 \mathrm{~min}$ prior to the WAT, and HIT training to both the control and the supplemented group. The latter comprised a group of healthy students studied over six weeks, with a significant improvement in PP being obtained.

\section{Creatine}

Earnest al. [56] carried out a study on experienced strength athletes, in which following 14 days of creatine supplementation (not specifying the amount), they obtained a significant improvement in power levels in the WAT. Casey et al. [57] also recorded improvements in the work performed (peak and total) during a maximum isokinetic test following supply of a $20 \mathrm{~g}$ supplement of creatine per day over five days.

In the same vein, after supplying $20 \mathrm{~g}$ of creatine daily to three subjects (plus a placebo group and a control group, Odland et al. [58] found no improvement in power in a WAT, although higher total amounts of Pcr and ATP were observed in the muscle biopsies carried out. They concluded that these three days of supplementation might be too few for performance improvement in a supra-maximal test.

In the study conducted by Birch R. and Noble D [59], significant improvements were obtained in peak and average power in a maximum isokinetic test of $30 \mathrm{~s}$ following five days' supplementation with four doses of $5 \mathrm{~g}$ each per day.

Lastly, in a systematic review carried out by Mielgo-Ayuso, J et al. [60] on the effect of creatine on the performance of football players, they concluded that creatine supplementation with a loading dose of 20-30 g/day, divided into 3-4 times per day, taken for 6-7 days and followed over 9 weeks with $5 \mathrm{~g} /$ day or with a low dose of $3 \mathrm{mg} / \mathrm{kg} /$ day over 14 days, has positive effects on the improvement of physical performance tests related to anaerobic metabolism in such football players.

\section{$\beta$-Alanine}

Supplementation with $\beta$-alanine could be an important nutritional strategy, as it was shown that Carnosine causes a buffer effect on hydrogen ions, improving the $\mathrm{pH}$ 
range of the active muscle, and preventing or reducing fatigue [61]. Hobson et al. [62] refer to the evidence of an ergogenic effect in high-intensity exercises following $\beta$-alanine supplementation, especially in exercises of between 1 and $4 \mathrm{~min}$ in duration. However, the meta-analysis conducted by these authors shows that exercises of less than $60 \mathrm{~s}$ in duration do not improve performance following $\beta$-alanine supplementation, although they highlight the importance of researchers noting factors such as a blind and control group, the purity of the supplement, and test reliability.

In a study on college football players (highly trained athletes) in which the subjects were supplemented with $4.5 \mathrm{~g}$ of $\beta$-alanine over 30 days, there was no performance improvement in a $60 \mathrm{~s}$ WAT [63].

However, in research evaluating the performance of 18 female football players following 30 days of supplementation with $\beta$-alanine at a rate of $2.4 \mathrm{~g}$ per day, an improvement in the WAT was observed at PP and MP. [64].

A further study by Ramzi, A et al. [65] on active subjects who were given $5 \mathrm{~g}$ of $\beta$-alanine per day (divided into two or three shots per day) for one week found no improvement in power levels obtained in the WAT, although an increase in both maximum and average cadence was recorded.

Cosgrove, R. [66] also researched whether applying $3.2 \mathrm{~g}$ per day or $6.4 \mathrm{~g}$ per day of $\beta$-alanine over 4 weeks improved the results of a WAT in 23 untrained adult males and observed no improvement in peak power and fatigue rate. He, therefore, concluded that although many studies reinforce the idea that $\beta$-alanine improves anaerobic performance, there are also many variables to be taken into account to substantiate this claim: composition of the subjects' muscle fibres, duration of the test and control of the training carried out by the subjects during the period in which the supplement is taken.

Lastly, and in the same vein, Smith et al. [67] explained the of range results obtained following supplementation with $\beta$-alanine by the variety of supplementation periods used, the duration of the stimulus to which the subjects are exposed and the subjects' level of training. They concluded that a $30 \mathrm{~s}$ stimulus seems too short to be influenced by supplementation of $\beta$-alanine.

\section{Caffeine}

There are several studies related to the ergogenic effects of caffeine and performance in the WAT. For example, in a study conducted on nine active subjects who were given $6 \mathrm{mg} / \mathrm{kg}$ body weight of caffeine, Greer, F. et al. [68] reported an ergolytic effect of caffeine intake compared to placebo on energy production (power generated). In contrast, no significant effect was observed with caffeine intake in 18 active men, who were given $5 \mathrm{mg} / \mathrm{kg}$ body weight, in follow-up work by the same authors, Greer, F. et al. [69].

On the other hand, in a study by Anderson et al. [70] on nine experienced cyclists, who were given $280 \mathrm{mg}$ or placebo and performed the WAT with $9 \%$ of body mass as resistance, they found no significant correlation between caffeine intake and anaerobic performance in such cyclists. Additionally, when Chtourou, H. et al. [71] provided some 22 male PE students with a drink containing $80 \mathrm{mg}$ of caffeine, $1 \mathrm{~g}$ of taurine and $27 \mathrm{~g}$ of carbohydrates, while the control group was given a drink with carbohydrates but no taurine or caffeine, improvements were recorded in PP and MP following a WAT with an $8.7 \%$ endurance of body weight.

Most of the studies that explored this issue have small sample sizes, which, as a result, may have little power to detect any statistical significance (at an a priori alpha level of 0.05), when in fact, there may be a real effect. A way to alleviate these limitations (by increasing statistical power over individual studies) is to perform a meta-analysis, and a 2017 study exists on this topic by Jozo Grgic et al. [72]. This meta-analysis, on which I base the conclusion of the ergonomic effect of caffeine on performance in the WAT, concluded after reviewing 16 studies that met the characteristics deemed necessary by the author, that there was a significant difference between trials with a placebo and with caffeine in the production of maximum and average power. Similarly, Duncan MJ et al. [73] observed an 
improvement in maximum power in the WAT when providing 22 males with $5 \mathrm{mg} / \mathrm{kg}$, although they did not observe any improvements in MP or PP.

It is very important to highlight the idea referred to by Glaister, M. et al. [74] in their research. In addition to finding an ergogenic improvement with caffeine $(5 \mathrm{mg} / \mathrm{kg}$ body mass) in PP obtained in repeated $6 \mathrm{~s}$ sprints performed by 14 well-trained men, they concluded that perhaps the reason why many of the previous studies into the ergogenic effects of caffeine on maximum power did not achieve higher power levels might be that they used too small an amount. It may also be, as Del Coso, J. et al. [75] found, that although improvements in MP of a WAT performed by healthy subjects with an intake of $3 \mathrm{mg} / \mathrm{kg}$ were observed, those improvements varied between $1 \%$ and $9 \%$, thus underlining the importance of the existence of responders and non-responders.

It is not only important to indicate the amount of caffeine supplied by researchers in order to control its ergogenic effects but also the number of days and its tolerance. Lara, B et al. [76] conducted a study on 11 active people who were given $3 \mathrm{mg} / \mathrm{kg}$ body mass per day over 20 days and evaluated their effects in a modified WAT test $(15 \mathrm{~s})$ three times per week. They observed how the magnitude of the ergogenic effect of caffeine compared to placebo was greater on the first day of ingestion and then steadily decreased. They showed a continuous ergogenic effect with daily caffeine intake over 15 to 18 days and, subsequently, changes in the magnitude of this effect suggested a gradually increasing tolerance.

Although they did not conduct research directly related to the amount or effect of caffeine intake, Anderson et al. [77] recorded improvements in tests related to the placebo effect of caffeine and concluded that the improvement in caffeine performance of the WAT might be due to psychological rather than physiological reasons.

Lastly, it is important to note that improvements in WAT results with caffeine supplementation are observed in both trained and untrained subjects. Jodra et al. [78] recorded improvements in PP and MP as well as in the time needed to reach PP in both trained and untrained subjects who were administered a dose of $6 \mathrm{mg} / \mathrm{kg}$.

Nitrate

Both, Cuenca et al. [54] and Jodra et al. [79] analysed the effect of nitrate supplementation on different variables, including power generated in the WAT. They saw how 15 subjects increased their PP and decreased the time to reach this PP following nitrate supplementation. Dominguez et al. [80] also found improvements in PP, albeit only a tendency to improve in reaching it over time (without this being deemed significant) after supplementing 15 trained men with $5.6 \mathrm{mmol} / \mathrm{L}$. Lastly, Ballmann et al. [81] supplemented 11 active women before they went on to perform two $15 \mathrm{~s}$ tests, and recorded improvements in their measured power as well as in the work conducted during the tests.

\section{Other Substances}

There are other less researched substances such as:

Nicotine: Meier, J [82] conducted a thesis on the effect of nicotine on performance in the WAT. He found it caused no ergogenic effect;

Gold root extract: Ballmann et al. [83] studied the effect of gold root extract (GRE) supplementation on WAT performance. Although the researchers performed a $15 \mathrm{~s}$ test instead of the original $30 \mathrm{~s}$ test, they observed improvements in PP and MP of the supplemented subjects while at the same time failing to observe any improvements in the subjects' FI;

Arginine: Olek et al. [84] studied the effect of $2 \mathrm{~g}$ of arginine taken before performing the WAT and no significant improvements in PP results were obtained from the test;

Salbutanol: Le Panse et al. [85] supplemented eight strength-trained and seven sedentary male athletes over 3 weeks by administering salbutamol $12 \mathrm{mg} /$ day. They obtained improvements in PP, and two of the groups were analysed within the time taken to reach it.

Although there are several studies researching the effect of different substances on WAT performance, it seems that this effect is conditioned by the amount administered, the time of supplementation or the individual response of the subjects to each substance. 
Taking these variables into account, it appears that bicarbonate, creatine and caffeine may have a positive effect on WAT performance.

\subsubsection{Genetic Variables}

By conducting a brief review of the genes related to performance so far in the WAT, we obtained the following results (Table 3):

Table 3. Performance-related genes in the WAT. Own elaboration.

\begin{tabular}{ccc}
\hline Gene & Effect on WAT Performance & Alleles Related to Positive Effect \\
\hline ACTN3 & Positive/Negative & RR \\
AMPD1 & Positive & \\
PPARA & Positive & CC \\
MCT1 T1470A & Positive & TT y AA \\
UCP2 & Positive & Ala55 \\
\hline
\end{tabular}

Except for the ACTN3 gene, which seems to have a contradictory bibliography [86-89], the other genes would seem to have a positive effect in their exposed forms [90-94] on PP and/or MP in the WAT.

It should be noted that some studies only gather data on PP and MP during the test and that all studies assess the effect of the gene on performance by taking into account PP and MP.

\subsubsection{Other Variables}

The following section provides brief reviews of other studies related to variables that may influence the goodness of the outcomes of the WAT, as well as the power data results obtained:

- $\quad$ Performing the WAT in a seated or standing position: McLester et al. [95] studied the performance of three seated and standing WAT on 35 subjects. There were no significant differences in power levels in the first tests performed while seated or standing. On the other hand, Wilson et al. [96] studied the influence of the subject's position on the bike (seated and standing) during three consecutive WAT, and found no significant differences between the two positions in seven elite skaters. Reiser et al., conversely, recorded improvements of $8 \%$ when the subjects performed the standing test [97]. It is likely that additional energy from the upper body can be transferred from the hip, which might explain these increases;

- $\quad$ Regarding the effect of the use of oval plates in the WAT, Meyers et al. [98] found no difference in the case study they conducted, while Rodriguez-Marroyo et al. [99] did not find improvements in the power levels reached in the WAT in 15 high-level cyclists;

- The effect that altitude has on the performance of the WAT seems to mainly affect its aerobic component, insofar as Bedu et al. [100] compared the power levels obtained in the WAT performed by young people acclimatised to altitude $(3700 \mathrm{~m})$ and others living practically at sea level $(330 \mathrm{~m})$. In doing so, they did not record any significant differences in PP but did record them in MP. McLellan et al. [101], in contrast, carried out a study on 15 subjects who were given two WAT, with and without hypoxia, and did not record any decrease in test power. Lastly, Fallon et al. [102] compared the effect of hypoxia in the test on elite football players, finding no significant differences in terms of power;

- $\quad$ Neither Bar-Or [10] nor Bullinger et al. [103] found any significant improvement in test scores due to verbal motivation during a test conducted on young and elite female athletes, respectively. However, Edwards et al. [104] recorded improvements in the WAT MP of 12 active individuals;

- $\quad$ LaVoie et al. [105] researched the performance of the test with or without toe stirrups. After analysing 50 university students, they concluded that the use of cleats during the test improves all test scores (more than 10\%); 
- The effects of the length of the connecting rod in the WAT were studied by Imbar $\mathrm{O}$ et al. Although the length of the connecting rod did modify cadences during the test, it failed to modify power levels [106];

- As far as the time of day is concerned, in an initial study, twelve subjects carried out the WAT on 12 different occasions (duplicated measurements at 02:00, 06:00, 10:00, 14:00, 18:00 and 22:00), recording no significant differences with regard to PP and MP [107]. For their part, Lericollais et al. [108] analysed an increase in PP and FI in the comparison made between a WAT at 6:00 or 18:00 in 20 active subjects. Chtourou et al. [109] also achieved improvements in PP in the test carried out at 17:00 compared to one at 7:00, in 22 active males. Souissi et al. [110] recorded improvements in PP and MP of the tests, taken by 12 physical education students, at 18:00 compared to those taken at 8:00. Lastly, Souissi et al. [111], as in previous research, recorded higher power data in PP and MP in the tests carried out in the afternoon (7:00 vs. 17:00);

- Koch et al. [112] studied the difference in power levels obtained on the WAT with and without the use of carbon templates in the course of which they obtained no significant differences in PP or PM;

- $\quad$ Recinto et al. [113] found no significant differences in performing the WAT with either mouth or nose breathing;

- $\quad$ Ricard et al. [114] studied the influence of variations in bicycle seat angle of $72^{\circ}$ or $82^{\circ}$ on muscle activation and power generation of experienced cyclists. Although quadriceps and hamstring activation varied, power levels were not modified by the change in angulation. For their part, Peveler et al. [115] studied the effect of adjusting the height of the saddle on power levels obtained on the WAT, concluding that the knee angle of 25 to $35^{\circ}$ makes it possible to reach higher levels more safely than at other angles;

- Jacobs [116] and Hosick et al. [117] studied the effect of dehydration on WAT performance. While in his thesis, Jacobs found no decrease in performance in passively dehydrated subjects by 2 to 4 and 5\%, Hosick et al. also found no decrease in power in the WAT conducted on 15 healthy dehydrated subjects;

- A systematic review was recently published that studied the effect of music on WAT performance, concluding that although it appears that it may help to improve PP and MP, more studies are needed to corroborate this claim [118];

- As far as the effect of temperature and humidity is concerned, there were no significant differences in PP when the WAT was performed under three different environmental conditions (neutral $\left(22-23{ }^{\circ} \mathrm{C}, 55-60 \%\right.$ relative humidity), hot-dry $\left(38-39{ }^{\circ} \mathrm{C}, 25-30 \%\right.$ relative humidity), and hot-humid $\left(30{ }^{\circ} \mathrm{C}, 85-90 \%\right.$ relative humidity) [119];

- Ballmann et al. [81] studied the effect of compression garments on WAT performance. They recorded a significant improvement in MP but not in PP or FI in a study on basketball players;

- $\quad$ Baker et al. [120] studied the effect of a Mediterranean diet, compared to a Western diet, on WAT performance in the short term. They compared the differences in performance of 11 active subjects following 4 days of the Mediterranean diet or 4 days of the Western diet. Although they obtained significant differences in aerobic tests (also analysed in the study), they failed to obtain any improvements in the power levels reached in the WAT;

- Levy et al. [121] studied the effect of 10 days of intermittent fasting on WAT performance, finding a decrease in PP in fasting subjects;

- $\quad$ Michalczyk et al. [122] did not observe any significant differences in power levels recorded, although they did so in the total work carried out and in physiological values such as lactate concentrations, following 4 weeks without ingesting carbohydrates or one week with a carbohydrate load;

- $\quad$ Souissi et al. [123] studied the effect of sleep deprivation in thirteen healthy males on WAT performance. While $24 \mathrm{~h}$ sleep deprivation did not result in any decrease in performance, $36 \mathrm{~h}$ sleep deprivation did result in a significant decrease; 
- $\quad$ Regarding the importance of being familiar with the test and having performed it previously, Barfield et al. [124] observed that by performing it previously, one experimental group improved power levels obtained on the test significantly compared to another group that had not previously performed it;

- The size of the chain or chainring used is also a variable that may modify the results obtained in the WAT. Clark et al. [125] compared results obtained in the test on 20 trained men with two different plate sizes, obtaining significant differences between both;

- The application of different stretching techniques before performing the WAT was also studied by Franco et al. [126] in 15 male participants, with decreases in power levels being observed as well as in the time needed to reach PP after stretching. Miller also found a significant decrease in PP performing static stretching before WAT [127];

- Afsari et al. [128] compared a classical warm-up with a full-body vibration warm-up without obtaining any significant differences, although they point out the importance of studying the effect of different types of vibration in greater depth;

- With the development of new cyclo-ergometers that record power data more comprehensively, it was possible to change the protocol by eliminating the output used. In the usual protocol, the WAT test commences with a moving start of around $60 \mathrm{rpm}$ against low resistance, and then the load is quickly established. Supporters of the swing start (between 60 and $100 \mathrm{rpm}$ ) assume that this provides a faster increase in maximum power. On the other hand, standardisation is easier with a stationary start, and it should be possible to improve its reliability. Both Coleman SGS et al. [129] and W.Clark et al. [125] studied the difference between the start launched and the start from a standstill, finding significant differences in PP and the time in which it is reached, in addition to the peak cadence recorded. Despite more time being required to reach the peak with a stationary start, PP was significantly $(11 \%)$ higher when compared to a moving start;

- The amount of lean body mass is one of the most important performance variables in the test, and when expressed in absolute values, the PP of a WAT is significantly lower in women. In one case studied, the difference between men and women was 51, 17 and $5 \%$ when PP was expressed as $\mathrm{W}, \mathrm{W} / \mathrm{kg}$ and $\mathrm{W} / \mathrm{kg}$ lean body mass, respectively [130]. In contrast to the power expressed as $\mathrm{W}$ or $\mathrm{W} / \mathrm{kg}$, the difference in PP in terms of lean body mass between genders was not found to be significant, while in another study, absolute PP was 35\% higher in men than in women [131]. This difference was only $10 \%$ when PP was related to kg lean body mass. Anthropometric variables accounted for less than $50 \%$ of the variation in PP in men, while in women, thigh volume represented $66 \%$ of the variation in PP [131];

- With regard to the type of cyclo-ergometer used for the test, or rather the type of resistance provided by the cyclo-ergometer used, there may be differences that modify the results obtained, since output power at crank level is greater than the power dissipated at flywheel level due to friction energy losses in the chain and sprockets. This energy loss is considered to be in the order of 5 to $9 \%$ [132]. In the case of a Monark ergometer (with which the test was initially designed), losses were around 2 and $4 \%$ for 150 and $300 \mathrm{~W}$, respectively [133].

WAT performance was compared between a cycle-ergometer with mechanical resistance and another with a magnetic brake. Fifteen healthy subjects performed a WAT on a mechanical resistance cyclo-ergometer and a magnetic resistance cyclo-ergometer, with no difference being found between the two in terms of PP. In the case of the magnetic cyclo-ergometer, PP was reached later, while MP was lower. The magnetic cyclo-ergometer provides clearly different performance measurements, albeit giving rise to WAT results that may be used to evaluate anaerobic fitness [134].

Ozkaya O. et al. also concluded that PP, MP, lowest power, fatigue rate, maximum speed as rpm and amount of total energy expenditure demonstrated high reliability in magnetic cyclo-ergometers [135]. Conversely, Lakomy et al. stated that friction-loaded 
cyclo-ergometers might underestimate the power generated by the subject because they do not take into account acceleration of the flywheel [136].

This review aims to analyse the variables of the protocol that affect the WAT result. Although much research has been carried out on this test, there is no consensus on the results obtained for many of the variables studied (ACTN3 gene or nitrate supplementation), and other variables have hardly been studied (compression garments or vibration warm-up). On the other hand, it would be interesting to study in depth the relationship between more current variables such as genetics or microbiota and performance in the WAT.

\section{Limitations}

The most important limitation of this paper is in the design used. Although the author is aware that the study selection and the lack of methodological quality assessment imply a high risk of bias, due to the number of articles included in the review and the wide variety of variables covered, it was difficult to use any other type of design. Indeed, there are reviews conducted for only one of the many variables discussed in this paper [118].

\section{Conclusions}

The aim of this review is to analyse the variables that may condition outcomes on the WAT. It was seen how the most widely studied variables such as duration of the test, the resistance applied or warm-up must be adjusted, especially depending on the objective and the characteristics of the subject being tested. On the other hand, less studied variables such as the biomechanics of the bike, the material used or the time of day can change the results obtained.

It is important to control and standardise all possible variables to ensure that the WAT is carried out correctly.

Funding: This research received no external funding.

Institutional Review Board Statement: Not applicable.

Informed Consent Statement: Not applicable.

Conflicts of Interest: The author declares no conflict of interest.

\section{References}

1. Vandewalle, H.; Pérès, G.; Monod, H. Standard anaerobic exercise tests. Sports Med. 1987, 4, 268-289. [CrossRef]

2. Beneke, R.; Pollmann, C.H.; Bleif, I.; Leithäuser, R.; Hütler, M. How anaerobic is the Wingate anaerobic test for humans? Eur. J. Appl. Physiol. 2002, 87, 388-392.

3. Ayalon, A.; Inbar, O.; Bar-Or, O. Relationships among measurements of explosive strength and anaerobic power. In Biomechanics IV; Nelson, R.C., Morehouse, C.A., Eds.; International Series on Sports Sciences; Palgrave: London, UK, 1974; Volume 1, pp. 527-532.

4. Powers, S.; Howley, E. Exercise Physiology: Theory of Exercise Physiology and Application to Fitness and Performance, 2nd ed.; Brown \& Benchmark: Dubuque, IA, USA, 1990.

5. Dekerle, J.; Vanhatalo, A.; Burnley, M. Determination of critical power from a single test. Sci. Sports 2008, 23, 231-238. [CrossRef]

6. Tossavainen, M.; Nummela, A.; Paavolainen, L.; Mero, A.; Rusko, H. Comparison of two maximal anaerobic cycling tests. Int. J. Sports Med. 1996, 2, 120-124. [CrossRef] [PubMed]

7. Nummela, A.; Alberts, M.; Rijntjes, R.P.; Luhtanen, P.; Rusko, H. Reliability and validity of the maximal anaerobic running test. Int. J. Sports Med. 1996, 17, S97-S102. [CrossRef] [PubMed]

8. McArdle, W.; Katch, F.; Katch, V. Exercise Physiology: Energy, Nutrition, and Human Performance, 6th ed.; Lippencott Williams \& Wilkin: Baltimore, MD, USA, 2007.

9. Driss, T.; Vandewalle, H. The measurement of maximal (anaerobic) power output on a cycle ergometer: A critical review. Biomed. Res. Int. 2013, 589361. [CrossRef] [PubMed]

10. Bar-Or, O. The Wingate anaerobic test: An update on methodology, reliability and validity. Sports Med. 1987, 4, 381-394. [CrossRef] [PubMed]

11. Patton, J.F.; Duggan, A. An evaluation of tests of anaerobic power. Aviat. Space Environ. Med. 1987, 58, $237-242$.

12. Patton, J.; Murphy, M.; Frederick, F. Maximal power outputs during the Wingate anaerobic test. Int. J. Sports Med. 1985, 6, 82-85. [CrossRef] [PubMed] 
13. Inbar, O.; Dotan, R.; Bar-Or, O. Aerobic and anaerobic components of a thirty-second supramaximal cycling task. Med. Sci. Sports Exerc. 1976, 8. [CrossRef]

14. Evans, J.; Quinney, H. Determination of resistance settings for anaerobic power testing. Can. J. Appl. Sport Sci. 1981, 6, 53-56.

15. Mendez-Villanueva, A.; Bishop, D.; Hamer, P. Reproducibility of a 6-s maximal cycling sprint test. J. Sci. Med. Sport 2007, 10, 323-326. [CrossRef]

16. Granier, P.; Mercier, B.; Mercier, J.; Anselme, F.; Prefaut, C. Aerobic and anaerobic contribution to Wingate test performance in sprint and middle-distancerunners. Eur. J. Appl. Physiol. Occup. Physiol. 1995, 70, 58-65. [CrossRef]

17. Hopkins, W.G.; Schabort, E.J.; Hawley, J.A. Reliability of power in physical performance tests. Sports Med. 2001, 31, 211-234. [CrossRef]

18. Calbet, J.A.L.; Chavarren, J.; Dorado, C. Fractional use of anaerobic capacity during a 30- and a 45-s Wingate test. Eur. J. Appl. Physiol. Occup. Physiol. 1997, 76, 308-313. [CrossRef] [PubMed]

19. Calbet, J.A.L.; de Paz, J.A.; Garatachea, N.; De Vaca, S.C.; Chavarren, J. Anaerobic energy provision does not limit Wingate exercise performance in endurance-trained cyclists. J. Appl. Physiol. 2003, 94, 668-676. [CrossRef] [PubMed]

20. Janot, J.M.; Beltz, N.M.; Dalleck, L.D. Multiple off-ice performance variables predict on-ice skating performance in male and female division III ice hockey players. J. Sports Sci. Med. 2015, 14, 522-529. [PubMed]

21. Jacobs, I.; Tesch, P.A.; Bar-Or, O.; Karlsson, J.; Dotan, R. Lactate in human skeletal muscle after 10 and 30 s of supramaximal exercise. J. Appl. Physiol. 1983, 55, 365-367. [CrossRef]

22. Santos, E.L.; Novaes, J.S.; Reis, V.; Giannellaneto, A. Low sampling rates bias outcomes from the Wingate test. Int. J. Sports Med. 2010, 31, 784-789. [CrossRef] [PubMed]

23. Zajac, A.; Jarzabek, R.; Waskiewicz, Z. The diagnostic value of the 10- and 30-second wingate test for competitive athletes. J. Strength Cond. Res. 1999, 13, 16-19. [CrossRef]

24. Attia, A.; Hachana, Y.; Chaabene, H.; Gaddour, A.; Neji, Z.; Shephard, R.J.; Chelly, M.S. Reliability and validity of a 20-s alternative to the wingate anaerobic test in team sport male athletes. PLoS ONE. 2014, 9, e114444. [CrossRef] [PubMed]

25. Stickley, C.D.; Hetzler, R.K.; Kimura, I.F. Prediction of anaerobic power values from an abbreviated WAnT protocol. J. Strength Cond. Res. 2008, 22, 958-965. [CrossRef] [PubMed]

26. Hernández-Belmonte, A.; Buendía-Romero, A.; Martínez-Cava, A.; Courel-lbáñez, J.; Mora-Rodríguez, R.; Pallarés, J.G. Wingate test, when time and overdue fatigue matter: Validity and sensitivity of two time-shortened versions. Appl. Sci. 2020, 10, 8002. [CrossRef]

27. Herbert, P.; Sculthorpe, N.; Baker, J.S.; Grace, F. Validation of a six second cycle test for the determination of peak power output. Res. Sports Med. 2015, 23, 115-125. [CrossRef] [PubMed]

28. Hachana, Y.; Attia, A.; Nassib, S.; Shephard, R.J.; Chelly, M.S. Test-retest reliability, criterion-related validity, and minimal detectable change of score on an abbreviated Wingate test for field sport participants. J. Strength Cond. Res. 2012, 26, 1324-1330. [CrossRef] [PubMed]

29. Laurent, C.M.; Meyers, M.C.; Robinson, C.A.; Green, J.M. Cross-validation of the 20- versus 30-s Wingate anaerobic test. Eur. J. Appl. Physiol. 2007, 100, 645-651. [CrossRef] [PubMed]

30. Carey, D.G.; Richardson, M.T. Can Aerobic and anaerobic power be measured in a 60-second maximal test? J. Sports. Sci. Med. 2003, 2, 151-157.

31. Craig, N.P.; Pyke, F.S.; Norton, K.I. Specificity of test duration when assessing the anaerobic lactacid capacity of high-performance track cyclists. Int. J. Sports Med. 1989, 10, 237-242. [CrossRef]

32. Withers, R.T.; Sherman, W.M.; Clark, D.G.; Esselbach, P.C.; Nolan, S.R.; Mackay, M.H.; Brinkman, M. Muscle metabolism during 30, 60 and 90 s of maximal cycling on an air-braked ergometer. Eur. J. Appl. Physiol. Occup. Physiol. 1991, 63, 354-362. [CrossRef] [PubMed]

33. Vandewalle, H.; Peres, G.; Heller, J.; Panel, J.; Monod, H. Force-velocity relationship and maximal power on a cycle ergometer. Eur. J. Appl Physiol. Occup. Physiol. 1987, 56, 650-656. [CrossRef]

34. Dotan R, Bar-Or, O. Load optimization for the Wingate Anaerobic Test. Eur. J. Appl. Physiol. Occup. Physiol. 1983, 51, $409-417$.

35. Bradley, A.L.; Ball, T.E. The Wingate test: Effect of load on the power outputs of female athletes and nonathletes. J. Appl. Sport Sci. Res. 1992, 6, 193-199. [CrossRef]

36. Linossier, M.T.; Dormois, D.; Fouquet, R.; Geyssant, A.; Denis, C. Use of the force-velocity test to determine the optimal braking force for a sprint exercise on a friction-loaded cycle ergometer. Eur. J. Appl. Physiol. Occup. Physiol. 1996, 74, 420-427. [CrossRef]

37. Bediz, C.S.; Gökbel, H.; Kara, M.; Üçok, K.; Cikrikçi, E.; Ergene, N. Comparison of the aerobic contributions to Wingate anaerobic tests performed with two different loads. J. Sports Med. Phys. Fit. 1998, 38, 30-34.

38. Jaafar, H.; Rouis, M.; Coudrat, L.; Attiogbé, E.; Vandewalle, H.; Driss, T. Effects of load on wingate test performances and reliability. J Strength Cond Res. 2014, 28, 3462-3468. [CrossRef] [PubMed]

39. Jaafar, H.; Rouis, M.; Attiogbé, E.; Vandewalle, H.; Driss, T. Comparative study between the Wingate and force-velocity anaerobic cycling tests: Effect of physical fitness. Int. J. Sports Physiol. Perform. 2016, 11, 48-54. [CrossRef] [PubMed]

40. Richmond, S.R.; Whitman, S.A.; Acree, L.S.; Olson, B.D.; Carper, M.J.; Godard, M.P. Power output in trained male and female cyclists during the wingate test with increasing flywheel resistance. J. Exerc. Physiol. 2011, 14, 46-53.

41. Hermina, W. The Effects of Different Resistances on Peak Power during the Wingate Anaerobic Test. A. Ph.D. Thesis, Oregon State University, Corvallis, OR, USA, 1999. 
42. Üçok, K.; Gökbel, H.; Okudan, N. The load of the Wingate test: According to the body weight or lean body mass. Eur. J. Gen. Med. 2005, 2, 10-13. [CrossRef]

43. MacIntosh, B.R.; Rishaug, P.; Svedahl, K. Assessment of peak power and short-term work capacity. Eur. J. Appl. Physiol. 2003, 88, 572-579. [CrossRef]

44. Vargas, N.T.; Robergs, R.A.; Klopp, D.M. Optimal loads for a 30-s maximal power cycle ergometer test using a stationary start. Graefe's Arch. Clin. Exp. Ophthalmol. 2014, 115, 1087-1094. [CrossRef]

45. Poprzęcki, S.; Zajac, A.; Wower, B.; Cholewa, J. The affects of a warm-up and the recovery interval prior to exercise on anaerobic power and acid-Base balance in man. J. Hum. Kinet. 2007, 18, 15-28.

46. Frikha, M.; Chaâri, N.; Gharbi, A.; Souissi, N.; Mezghanni, N. Influence of warm-up duration and recovery interval prior to exercise on anaerobic performance. Biol. Sport 2016, 33, 361-366. [CrossRef]

47. Tomaras, E.K.; MacIntosh, B.R. Less is more: Standard warm-up causes fatigue and less warm-up permits greater cycling power output. J. Appl. Physiol. 2011, 111, 228-235. [CrossRef] [PubMed]

48. Doma, K.; Leicht, A.S.; Schumann, M.; Nagata, A.; Senzaki, K.; Woods, C.E. Postactivation potentiation effect of overloaded cycling on subsequent cycling Wingate performance. J. Sports Med. Phys. Fit. 2019, 59, 217-222. [CrossRef]

49. Ramierz, E.B.; Williford, H.N.; Olson, M.S. Effects of a static stretching versus conventional warm-up on power output during wingate cycle performance. Med. Sci. Sports Exerc. 2007, 39, S353. [CrossRef]

50. Kendall, B.J. The acute effects of static stretching compared to dynamic stretching with and without an active warm up on anaerobic performance. Int. J. Exerc. Sci. 2017, 10, 53-61. [PubMed]

51. Zabala, M.; Requena, B.; Muñoz, C.S.; González-Badillo, J.J.; García, I.; Ööpik, V.; Pääsuke, M. Effects of sodium bicarbonate ingestion on performance and perceptual responses in a laboratory-simulated BMX cycling qualification series. J. Strength Cond. Res. 2008, 22, 1645-1653. [CrossRef]

52. Douroudos, I.I.; Fatouros, I.G.; Gourgoulis, V.; Jamurtas, T.; Tsitsios, T.; Hatzinikolaou, A.; Margonis, K.; Mavromatidis, K.; Taxildaris, K. Dose-related effects of prolonged NaHCO3 ingestion during high-intensity exercise. Med. Sci. Sports Exerc. 2006, 38, 1746-1753. [CrossRef] [PubMed]

53. Parry-Billings, M.; MacLaren, D.P.M. The effect of sodium bicarbonate and sodium citrate ingestion on anaerobic power during intermittent exercise. Graefe's Arch. Clin. Exp. Ophthalmol. 1986, 55, 524-529. [CrossRef]

54. Cuenca, E.; Jodra, P.; Pérez-López, A.; González-Rodríguez, L.G.; Da Silva, S.F.; Veiga-Herreros, P.; Domínguez, R. Effects of beetroot juice supplementation on performance and fatigue in a 30-s all-out sprint exercise: A randomized, double-blind cross-over study. Nutrients 2018, 10, 1222. [CrossRef]

55. Wang, J.; Qiu, J.; Yi, L.; Hou, Z.; Benardot, D.; Cao, W. Effect of sodium bicarbonate ingestion during 6 weeks of HIIT on anaerobic performance of college students. J. Int. Soc. Sports Nutr. 2019, 16, 18. [CrossRef]

56. Earnest, C.P.; Snell, P.G.; Rodriguez, R.; Almada, A.L.; Mitchell, T.L. The effect of creatine monohydrate ingestion on anaerobic power indices, muscular strength and body composition. Acta Physiol. Scand. 1995, 153, 207-209. [CrossRef]

57. Casey, A.; Constantin-Teodosiu, D.; Howell, S.; Hultman, E.; Greenhaff, P. Creatine ingestion favorably affects performance and muscle metabolism during maximal exercise in humans. Am. J. Physiol. Metab. 1996, 271, E31-E37. [CrossRef] [PubMed]

58. Odland, L.M.; MacDougall, J.D.; Tarnopolsky, M.A.; Elorriaga, A.; Borgmann, A. Effect of oral creatine supplementation on muscle [PCr] and short-term maximum power output. Med. Sci. Sports Exerc. 1997, 29, 216-219. [CrossRef]

59. Birch, R.; Noble, D.; Greenhaff, P. The influence of dietary creatine supplementation on performance during repeated bouts of maximal isokinetic cycling in man. Eur. J. Appl. Physiol. Occup. Physiol. 1994, 69, 268-270. [CrossRef]

60. Mielgo-Ayuso, J.; Calleja-Gonzalez, J.; Marqués-Jiménez, D.; Caballero-García, A.; Córdova, A.; Fernández-Lázaro, D. Effects of creatine supplementation on athletic performance in soccer players: A systematic review and meta-analysis. Nutrients 2019, 11, 757. [CrossRef] [PubMed]

61. Harris, R.C.; Tallon, M.J.; Dunnett, M.; Boobis, L.; Coakley, J.; Kim, H.J.; Fallowfield, J.L.; Hill, C.A.; Sale, C.; Wise, J.A. The absorption of orally supplied beta-alanine and its effect on muscle car- nosine synthesis in human vastus lateralis. Amino Acids 2006, 30, 279-289. [CrossRef]

62. Hobson, R.M.; Saunders, B.; Ball, G.; Harris, R.C.; Sale, C. Effects of $\beta$-alanine supplementation on exercise performance: A meta-analysis. Amino Acids 2012, 43, 25-37. [CrossRef] [PubMed]

63. Hoffman, J.R.; Ratamess, N.A.; Faigenbaum, A.D.; Ross, R.; Kang, J.; Stout, J.R.; Wise, J.A. Short-duration beta-alanine supplementation increases training volume and reduces subjective feelings of fatigue in college football players. Nutr. Res. 2008, 28, 31-35. [CrossRef]

64. Rodríguez Rodríguez, F.; Delgado Ormeño, A.; Rivera Lobos, P.; Tapia Aranda, V.; Cristi-Montero, C. Efectos de la suplementación con $\beta$-alanina en pruebas de wingate en futbolistas universitarios. Nutr. Hosp. 2014, 31, 430-435.

65. Ramzi, A.; Rashad, A. Effect of seven days of beta-alanine supplementation on cycle ergometer wingate test performance. Int. J. Coach. Sci. 2017, 11, 45-59.

66. Cosgrove, R. Supplemental Beta-Alanine and Its Effects on Anaerobics Exercise Performance Using the Wingate Anaerobic Test. Master's Thesis, Bastyr University, Kenmore, WA, USA, 2016.

67. Smith, A.E.; Walter, A.A.; Graef, J.L.; Kendall, K.L.; Moon, J.R.; Lockwood, C.M.; Fukuda, D.H.; Beck, T.W.; Cramer, J.T.; Stout, J.R. Effects of $\beta$-alanine supplementation and high-intensity interval training on endurance performance and body composition in men; a double-blind trial. J. Int. Soc. Sports Nutr. 2009, 6. [CrossRef] 
68. Greer, F.; McLean, C.; Graham, T.E. Caffeine, performance, and metabolism during repeated Wingate exercise tests. J. Appl. Physiol. 1998, 85, 1502-1508. [CrossRef]

69. Greer, F.; Morales, J.; Coles, M. Wingate performance and surface EMG frequency variables are not affected by caffeine ingestion. Appl. Physiol. Nutr. Metab. 2006, 31, 597-603. [CrossRef]

70. Anderson, D.E.; LeGrand, S.E.; McCart, R.D. Effect of caffeine on sprint cycling in experienced cyclists. J. Strength Cond. Res. 2018, 32, 2221-2226. [CrossRef] [PubMed]

71. Chtourou, H.; Trabelsi, K.; Ammar, A.; Shephard, R.J.; Bragazzi, N.L. Acute effects of an "energy drink" on short-term maximal performance, reaction times, psychological and physiological parameters: Insights from a randomized double-blind, placebocontrolled, counterbalanced crossover trial. Nutrients 2019, 11, 992. [CrossRef]

72. Grgic, J.; Trexler, E.T.; Lazinica, B.; Pedisic, Z. Effects of caffeine intake on muscle strength and power: A systematic review and meta-analysis. J. Int. Soc. Sports Nutr. 2018, 15, 11. [CrossRef] [PubMed]

73. Duncan, M.J.; Eyre, E.; Grgic, J.; Tallis, J. The effect of acute caffeine ingestion on upper and lower body anaerobic exercise performance. Eur. J. Sport Sci. 2019, 19, 1359-1366. [CrossRef]

74. Glaister, M.; Muniz-Pumares, D.; Patterson, S.D.; Foley, P.; McInnes, G. Caffeine supplementation and peak anaerobic power output. Eur. J. Sport Sci. 2014, 15, 400-406. [CrossRef]

75. Del Coso, J.; Lara, B.; Ruiz-Moreno, C.; Salinero, J.J. Challenging the myth of non-response to the ergogenic effects of caffeine ingestion on exercise performance. Nutrients 2019, 11, 732. [CrossRef]

76. Lara, B.; Ruiz, C.; Salinero, J.J.; Del Coso, J. Time course of tolerance to the performance benefits of caffeine. PLoS ONE 2019, 14, e0210275. [CrossRef] [PubMed]

77. Anderson, D.E.; German, R.E.; Harrison, M.E.; Bourassa, K.N.; Taylor, C.E. Real and perceived effects of caffeine on sprint cycling in experienced cyclists. J. Strength Cond. Res. 2020, 34, 929-933. [CrossRef] [PubMed]

78. Jodra, P.; Rodríguez, L.; Sánchez-Oliver, A.J.; López-Samanes, A.; Pérez-López, A.; Veiga-Herreros, P.; Juan, A.F.S.; Domínguez, R. Effects of caffeine supplementation on physical performance and mood dimensions in elite and trained-recreational athletes. $J$. Int. Soc. Sports Nutr. 2020, 17, 2. [CrossRef]

79. Jodra, P.; Domínguez, R.; Sánchez-Oliver, A.J.; Veiga-Herreros, P.; Bailey, S.J. Effect of beetroot juice supplementation on mood, perceived exertion, and performance during a 30-s Wingate test. Int. J. Sports Physiol. Perform. 2019, 15, 243-248. [CrossRef]

80. Domínguez, R.; Garnacho-Castaño, M.; Cuenca, E.; García-Fernández, P.; Muñoz-González, A.; De Jesús, F.; Estevan, M.D.C.L.; Da Silva, S.F.; Herreros, P.V.; Maté-Muñoz, J.L. Effects of Beetroot juice supplementation on a 30-s high-intensity inertial cycle ergometer test. Nutrients 2017, 9, 1360. [CrossRef]

81. Ballmann, C.; Hotchkiss, H.; Marshall, M.; Rogers, R. The effect of wearing a lower body compression garment on anaerobic exercise performance in division I NCAA basketball players. Sports 2019, 7, 144. [CrossRef] [PubMed]

82. Meier, J. Effect of Nicotine and Muscle Performance Using a Wingate Anaerobic Test on Collegiate Football Players. Master's Thesis, The University Of Wisconsin-Whitewater, Whitewater, WI, USA, 2006.

83. Ballmann, C.G.; Maze, S.B.; Wells, A.C.; Marshall, M.R.; Rogers, R.R. Effects of short-term Rhodiola Rosea (golden root extract) supplementation on anaerobic exercise performance. J. Sports Sci. 2017, 37, 998-1003. [CrossRef]

84. Olek, R.; Ziemann, E.; Grzywacz, T.; Kujach, S.; Luszczyk, M.; Antosiewicz, J.; Laskowski, R. A single oral intake of arginine does not affect performance during repeated Wingate anaerobic test. J. Sports Med. Phys. Fit. 2010, 50, 52-56.

85. Le Panse, B.; Collomp, K.; Portier, H.; Lecoq, A.-M.; Jaffré, C.; Beaupied, H.; Richard, O.; Benhamou, L.; De Ceaurriz, J.; Courteix, D. Effects of short-term salbutamol ingestion during a Wingate test. Int. J. Sports Med. 2004, 26, 518-523. [CrossRef]

86. Norman, B.; Esbjörnsson, M.; Rundqvist, H.; Osterlund, T.; Von Walden, F.; Tesch, P.A. Strength, power, fiber types, and mRNA expression in trained men and women with different ACTN3 R577X genotypes. J. Appl. Physiol. 2009, 106, 959-965. [CrossRef]

87. Hanson, E.D.; Ludlow, A.T.; Sheaff, A.K.; Park, J.; Roth, S. ACTN3 genotype does not influence muscle power. Int. J. Sports Med. 2010, 31, 834-838. [CrossRef]

88. Pennington, C. Determining the anaerobic power output differences between the genders in untrained adults. Am. Int. J. Contemp. Res. 2014, 4, 64-77.

89. Atanasov, P.; Djarova, T.; Kalinski, M.; Petrov, L.; Kaneva, R.; Mugandani, S.; Watson, G.; Jemni, M. ACTN3 and AMPD1 polymorphism and genotype combinations in bulgarian athletes performing wingate test. J. Sports Sci. 2015, 3. [CrossRef]

90. Norman, B.; Sabina, R.L.; Jansson, E. Regulation of skeletal muscle ATP catabolism by AMPD1 genotype during sprint exercise in asymptomatic subjects. J. Appl. Physiol. 2001, 91, 258-264. [CrossRef]

91. Fischer, H.; Esbjörnsson, M.; Sabina, R.L.; Strömberg, A.; Peyrard-Janvid, M.; Norman, B. AMP deaminase deficiency is associated with lower sprint cycling performance in healthy subjects. J. Appl. Physiol. 2007, 103, 315-322. [CrossRef] [PubMed]

92. Petr, M.; Stastny, P.; Pecha, O.; Šteffl, M.; Šeda, O.; Kohlíková, E. Correction: PPARA Intron Polymorphism Associated with Power Performance in 30-s Anaerobic Wingate Test. PLoS ONE 2015, 10. [CrossRef] [PubMed]

93. Kikuchi, N.; Fuku, N.; Matsumoto, R.; Matsumoto, S.; Murakami, H.; Miyachi, M.; Nakazato, K. The Association Between MCT1 T1470A Polymorphism and Power-Oriented Athletic Performance. Int. J. Sports Med. 2017, 38, 76-80. [CrossRef]

94. Bondareva, E.; Parfenteva, O.; Kozlov, A.; Zhuravleva, U.; Kosyakova, E.; Karelina, E.; Ketlerova, E.; Son'kin, V. The Ala/Val Polymorphism of the UCP2 Gene Is Reciprocally Associated with Aerobic and Anaerobic Performance in Athletes. Hum. Physiol. 2018, 44, 673-678. [CrossRef] 
95. McLester, J.; Green, J.; Chouinard, J. Effects of Standing vs. Seated Posture on Repeated Wingate Performance. J. Strength Cond. Res./Natl. Strength Cond. Assoc. 2004, 18, 816-820. [CrossRef]

96. Wilson, R.W.; Snyder, A.C.; Dorman, J.C. Analysis of Seated and Standing Triple Wingate Tests. J. Strength Cond. Res. 2009, 23, 868-873. [CrossRef]

97. Reiser, R.F.; Maines, J.M.; Eisenmann, J.C.; Wilkinson, J.G. Standing and seated Wingate protocols in human cycling. A comparison of standard parameters. Eur. J. Appl. Physiol. 2002, 88, 152-157. [CrossRef]

98. Meyers, A.C.; Pohlig, R.T.; Hopkins, J.Q. Positioning of elliptical chainrings during Wingate testing-A repeated measures case study. J. Sci. Cycl. 2016, 5. Available online: https://www.jsc-journal.com/index.php/JSC/article/view/275 (accessed on 20 October 2020).

99. Rodríguez-Marroyo, J.A.; García-López, J.; Chamari, K.; Córdova, A.; Hue, O.; Villa, J.G. The rotor pedaling system improves anaerobic but not aerobic cycling performance in professional cyclists. Eur. J. Appl. Physiol. 2009, 106, 87-94. [CrossRef] [PubMed]

100. Bedu, M.; Fellmann, N.; Spielvogel, H.; Falgairette, G.; Van Praagh, E.; Coudert, J. Force-velocity and 30-s Wingate tests in boys at high and low altitudes. J. Appl. Physiol. 1991, 70, 1031-1037. [CrossRef]

101. McLellan, T.M.; Kavanagh, M.F.; Jacobs, I. The effect of hypoxia on performance during $30 \mathrm{~s}$ or $45 \mathrm{~s}$ of supramaximal exercise. Graefe's Arch. Clin. Exp. Ophthalmol. 1990, 60, 155-161. [CrossRef] [PubMed]

102. Fallon, S.; Belcoe, A.; Shawcross, C.; May, A.; Monteverde, C.; McCann, D. Elite female athletes' ventilatory compensation to decreased inspired O2 during the wingate test. Res. Q. Exerc. Sport 2014, 86, 182-189. [CrossRef]

103. Bullinger, D.L.; Hearon, C.M.; Gaines, S.A.; Daniel, M.L. Concurrent Verbal Encouragement and Wingate Anaerobic Cycle Test Performance in Females: Athletes vs. Non-Athletes. Int. J. Exerc. Sci. 2012, 5, 239-244. [CrossRef] [PubMed]

104. Edwards, A.M.; Dutton-Challis, L.; Cottrell, D.; Guy, J.H.; Hettinga, F.J. Impact of active and passive social facilitation on self-paced endurance and sprint exercise: Encouragement augments performance and motivation to exercise. BMJ Open Sport Exerc. Med. 2018, 4, e000368. [CrossRef]

105. Lavoie, N.; Dallaire, J.; Brayne, S.; Barrett, D. Anaerobic testing using the Wingate and Evans-Quinney protocols with and without toe stirrups. Can. J. Appl. Sport Sci. J. Can. Sci. Appl. Sport 1984, 9, 1-5.

106. Inbar, O.; Dotan, R.; Trousil, T.; Dvir, Z. The effect of bicycle crank-length variation upon power performance. Ergonomics 1983, 26, 1139-1146. [CrossRef] [PubMed]

107. Down, A.; Reilly, T.; Parry-Billings, M. Time of day and performance of the Wingate AnaerobicTest. J. Sports Sci. 1985, 3, 214.

108. Lericollais, R.; Gauthier, A.; Bessot, N.; Davenne, D. Diurnal evolution of cycling biomechanical parameters during a 60-s Wingate test. Scand. J. Med. Sci. Sports 2010, 21, e106-e114. [CrossRef]

109. Chtourou, H.; Zarrouk, N.; Chaouachi, A.; Dogui, M.; Behm, D.G.; Chamari, K.; Hug, F.; Souissi, N. Diurnal variation in Wingate-test performance and associated electromyographic parameters. Chronobiol. Int. 2011, 28, 706-713. [CrossRef] [PubMed]

110. Souissi, N.; Driss, T.; Chamari, K.; Vandewalle, H.; Davenne, D.; Gam, A.; Fillard, J.-R.; Jousselin, E. Diurnal variation in Wingate test performances: Influence of active warm-up. Chronobiol. Int. 2010, 27, 640-652. [CrossRef] [PubMed]

111. Souissi, H.; Chtourou, H.; Chaouachi, A.; Chamari, K.; Souissi, N.; Amri, M. Time of day effects in EMG parameters during the wingate test in boys. J. Sports Sci. Med. 2012, 11, 380-386.

112. Koch, M.; Fröhlich, M.; Emrich, E.; Urhausen, A. The impact of carbon insoles in cycling on performance in the Wingate anaerobic test. J. Sci. Cycl. 2013, 2, 2-5.

113. Recinto, C.; Efthemeou, T.; Boffelli, P.T.; Navalta, J.W. Effects of nasal or oral breathing on anaerobic power output and metabolic responses. Int. J. Exerc. Sci. 2017, 10, 506-514.

114. Ricard, M.D.; Hills-Meyer, P.; Miller, M.G.; Michael, T.J. The effects of bicycle frame geometry on muscle activation and power during a wingate anaerobic test. J. Sports Sci. Med. 2006, 5, 25-32.

115. Peveler, W.W.; Pounders, J.D.; Bishop, P.A. Effects of saddle height on anaerobic power production in cycling. J. Strength Cond. Res. 2007, 21, 1023-1027.

116. Jacobs, I. The Effects of Thermal Dehydration on Performance of The Wingate Test of Anaerobic Power. Ph.D. Thesis, University of Windsor, Windsor, ON, Canada, 1979.

117. Hosick, P.A.; Sheris, A.; Alencewicz, J.S.; Matthews, E.L. Mild dehydration following voluntary water intake reduction does not affect anaerobic power performance. J. Sports Med. Phys. Fit. 2020, 60, 361-366. [CrossRef] [PubMed]

118. Castañeda-Babarro, A.; Marqués-Jiménez, D.; Calleja-González, J.; Viribay, A.; León-Guereño, P.; Mielgo-Ayuso, J. Effect of listening to music on Wingate Anaerobic test performance. A systematic review and meta-analysis. Int. J. Environ. Res. Public Health 2020, 17, 4564. [CrossRef]

119. Dotan, R.; Bar-Or, O. Climatic heat stress and performance in the Wingate anaerobic test. Graefe's Arch. Clin. Exp. Ophthalmol. 1980, 44, 237-243. [CrossRef]

120. Baker, M.E.; DeCesare, K.N.; Johnson, A.; Kress, K.S.; Inman, C.L.; Weiss, E.P. Short-term mediterranean diet improves endurance exercise performance: A randomized-sequence crossover trial. J. Am. Coll. Nutr. 2019, 38, 597-605. [CrossRef] [PubMed]

121. Levy, E.; Chu, T. Intermittent fasting and its effects on athletic performance. Curr. Sports Med. Rep. 2019, 18, 266-269. [CrossRef]

122. Michalczyk, M.M.; Chycki, J.; Zajac, A.; Maszczyk, A.; Zydek, G.; Langfort, J. Anaerobic performance after a low-carbohydrate $\operatorname{diet}(\mathrm{LCD})$ followed by 7 days of carbohydrate loading in male basketball players. Nutrients 2019, 11, 778. [CrossRef] [PubMed]

123. Souissi, N.; Sesboüé, B.; Gauthier, A.; Larue, J.; Davenne, D. Effects of one nights sleep deprivation on anaerobic performance the following day. Eur. J. Appl. Physiol. 2003, 89, 359-366. [CrossRef] 
124. Barfield, J.P.; Sells, P.D.; Rowe, D.A.; Hannigan-Downs, K. Practice effect of the Wingate anaerobic test. J. Strength Cond. Res. 2002, 16, 472-473.

125. Clark, N.W.; Wagner, D.R.; Heath, E.M. Influence of Velotron chainring size on Wingate anaerobic test. J. Sci. Med. Sport 2018, 21, 202-206. [CrossRef] [PubMed]

126. Franco, B.L.; Signorelli, G.R.; Trajano, G.; Costa, P.B.; De Oliveira, C.G. Acute effects of three different stretching protocols on the wingate test performance. J. Sports Sci. Med. 2012, 11, 1-7.

127. Miller, J.M. Acute effects of static stretching on Wingate testing in men. J. Sports Med. Phys. Fit. 2020, 60, 974-978. [CrossRef]

128. Afsari, M.; Ramezanpour, M.R.; Hejazi, S.M.; Bayati, M.; Farzad, B. The effect of whole-body vibration warm-up on performance of Wingate anaerobic test. Zahedan J. Res. Med. Sci. 2015, 17. [CrossRef]

129. Coleman, S.G.S.; Hale, T.H.E. A comparison of power outputs with rolling and stationary starts in the Wingate anaerobic test. J. Sports Sci. 1985, 3, 207.

130. Maud, P.J.; Shultz, B.B. Gender comparisons in anaerobic power and anaerobic capacity tests. Br. J. Sports Med. 1986, $20,51-54$. [CrossRef]

131. Murphy, M.M.; Patton, J.F.; A Frederick, F. Comparative anaerobic power of men and women. Aviat. Space Environ. Med. 1986, 57, 636-641. [PubMed]

132. Marks, L.S. The Mechanical Engineers Handbook; McGraw-Hill: New York, NY, USA, 1951.

133. Kyle, C.R.; Caiozzo, V.J. Experiments in human ergometry as applied to the design of human powered vehicles. Int. J. Sports Biomech. 1986, 2, 6-19. [CrossRef]

134. Micklewright, D.; Alkhatib, A.; Beneke, R. Mechanically versus electro-magnetically braked cycle ergometer: Performance and energy cost of the Wingate anaerobic test. Eur. J. Appl. Physiol. 2006, 96, 748-751. [CrossRef]

135. Ozkaya, O.; Balci, G.A.; As, H.; Vardarli, E. The Test-retest reliability of new generation power indices of Wingate all-out test. Sports 2018, 6, 31. [CrossRef] [PubMed]

136. Lakomy, H.K.A. Measurement of work and power output using friction-loaded cycle ergometers. Ergononomics 1986, $29,509-517$. [CrossRef] [PubMed] 